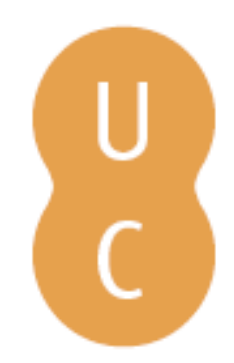

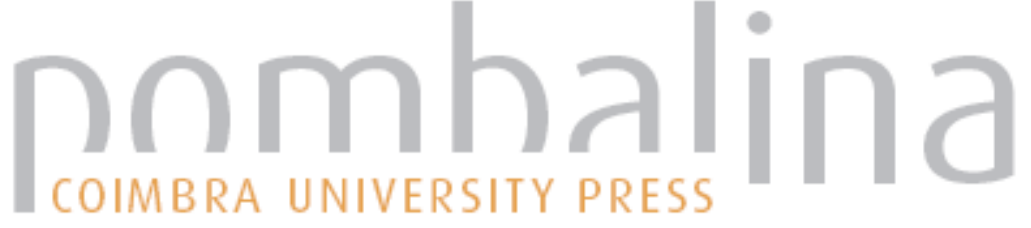

\section{Home-villages as a residence and revitalization system oh the territory}

Autor(es): $\quad$ Bordalo, Ana; Matos, Madalena Cunha

Publicado por: Imprensa da Universidade de Coimbra

URL

persistente:

URI:http://hdl.handle.net/10316.2/32528

DOI:

DOI:http://dx.doi.org/10.14195/978-989-26-0732-0_14

Accessed : $\quad$ 26-Apr-2023 07:09:52

A navegação consulta e descarregamento dos títulos inseridos nas Bibliotecas Digitais UC Digitalis, UC Pombalina e UC Impactum, pressupõem a aceitação plena e sem reservas dos Termos e Condições de Uso destas Bibliotecas Digitais, disponíveis em https://digitalis.uc.pt/pt-pt/termos.

Conforme exposto nos referidos Termos e Condições de Uso, o descarregamento de títulos de acesso restrito requer uma licença válida de autorização devendo o utilizador aceder ao(s) documento(s) a partir de um endereço de IP da instituição detentora da supramencionada licença.

Ao utilizador é apenas permitido o descarregamento para uso pessoal, pelo que o emprego do(s) título(s) descarregado(s) para outro fim, designadamente comercial, carece de autorização do respetivo autor ou editor da obra.

Na medida em que todas as obras da UC Digitalis se encontram protegidas pelo Código do Direito de Autor e Direitos Conexos e demais legislação aplicável, toda a cópia, parcial ou total, deste documento, nos casos em que é legalmente admitida, deverá conter ou fazer-se acompanhar por este aviso. 
MPRENSA DA

UNIVERSIDADE

DE COIMBRA

COIMBRA

UNIVERSITY

- PRESS 


\title{
HOME-VILLAGES AS A RESIDENCE AND REVITALIZATION SYSTEM OF THE TERRITORY
}

\author{
Ana Bordalo ${ }^{38}$, Madalena Cunha Matos ${ }^{39}$
}

\begin{abstract}
Home-villages in Portugal, as a system of residence and revitalization of the territory are the main objective of this work. Based on the case study of the Home-Village of São José de Alcalar, in Mexilhoeira Grande - Portimão, it seeks to identify rules of conception and space, as well as implementation systems that will contribute to establishing a special equity in habitation and also identifying the daily flows of the populations in their territory of action and influence, by examining the use of mobility systems and equipment.

The demographic challenge, with the increase in the number of people over 65 years and their higher longevity, adds the challenge of promoting relations of proximity and interaction of populations with their homes, as place of shelter, and the territory in which they move and work. It is necessary to establish a land structure and intergenerational architecture that removes physical and psychological obstacles, minimizing the isolation of the elderly population, where the introduction of the time factor in urban and architectural planning aims to encourage and enhance the social and civic participation of people in the community. Through the development and introduction of a balanced planning system, rural or/and urban land use too, the aim is to establish a qualified supply of housing, equipment, jobs and services to promote the establishment of a population which can fight the abandonment of the territory and its desertification.
\end{abstract}

38 Faculdade de Arquitectura da Universidade Técnica de Lisboa (FAUTL)

Email: ana.bordalo@gmail.com; Centro de Investigação em Arquitectura Design e Urbanismo (CIAUD).

39 Email: mcunhamatos@fa.utl.pt 
The relevance of this research relates to the timeliness of the theme and the necessity to create workable answers, contributing to the development of knowledge enhancement of housing problems, permanent or temporary, that despite concerns over accessibility and mobility needs for the aging population, it intended to be intergenerational.

Keywords: Territory; Home Village; Housing; Spatial Equity; Population Aged; Revitalization.

\section{Introduction}

\section{Contextualization of the theme}

The aging world population appears to reflect the developments of medical, scientific and technological knowledge, as well as the improvement of hygiene and sanitation in housing and in the territory. It is still relevant to include educational, cultural, political, social and economic factors, which influence the rates of fertility and life expectancy of populations and also their migration flows. In this context, population aging presents itself as a global problem, a reflection of globalization (Harper, 2009).

The $20^{\text {th }}$ century was marked as a time of high population growth. Between 1900 and 2000, there was a world population increase from 1.5 billion to over 6 billion, and this may increase to 8 or 9 billion until 2050. Projections indicate that, during the first half of the $21^{\text {th }}$ century, developed countries in Europe, North America, Japan, Australia and New Zealand, will register; at most, a slight increase of population, with the expectation of it stabilizing from there one, with maybe even a slight decrease occurring. Developing countries are expected to stabilize, as a consequence of the decrease in the fertility rate (Wilson, 2009).

In the transition from the $20^{\text {th }}$ to the $21^{\text {th }}$ century there were, within the European Union (EU)-15, more people of 60 and more years old than young ones under 15 years old. The convergence rate of longevity (aging at the top) with the decrease in fertility rate (aging at the base) reflects the aging demographic, where the coexistence of these two factors leads 
to a double aging, result in the increasing number of elderly in the total population and the decreasing number of young.

Migration may contribute to enhancing or reversing this process, as immigration appears as a retarding factor for aging and migration as a leverage factor. We conclude that although world population numbers will stabilize, the proportion of elderly people will continue to increase, with a significant rate of growth of people aged over 80 , and it is at this age where there will be the fastest growth worldwide (Harper, 2009).

World population aging is presented as a consequence of temporal stabilization in the population growth, verifying that the strong population growth in the twentieth century eased the aging process.

According to Jorge Gaspar (2009), the $20^{\text {th }}$ century was the century of population growth; the $21^{\text {th }}$ century will be the century of aging.

This work deals with the problem of population aging and how it interacts with the housing structure and the territory, where it belongs. It seeks to contribute to the promotion of a territorial structure and architectural intergenerational that minimizes or even eliminates the obstacles and the isolation of the (elderly) population, thereby aiming, for an improvement of their quality of life and integration in their family community and social support. It starts with an analysis of models/ systems of Home Villages, explores how these may be structural for a sustainable land - by offering qualified housing structures, employment and services - and thus promote the settling of the population, fighting desertification and abandonment of territory.

\section{Contextualizing of the theme in the Portuguese scenario}

In the early $21^{\text {th }}$ century, Portugal appears as one of the most aged countries in Europe; where for people who were born in 1960 there was an average life expectancy of 60.7 years for men and 66.4 years for women. For those born in 2010, this expectancy, rose to 76.14 years for men and 82.05 years for women, which represents an increase of nearly 15 years in six decades. 
There is also an increase in the population aged 75 or over. While in 1960 , this segment of the population accounted for $34 \%$ of the total population over 65 years, in 2001 it represented $41 \%$ and in 2008 it accounted for $46 \%$. Another factor that characterizes the Portuguese population is that for every five people 75 and over at least three are women (Rosa \& Chistas, 2010).

The results of the 2011 Census indicate that, in Portugal, a growth in the resident population of $2 \%$ was found in the last decade, which corresponds to about 205 thousand individuals. However, this value is lower than that recorded in the previous decade (1991-2001), where there had been a growth of $5 \%$.

Another important factor is the dual aging population in Portugal, where $19 \%$ of the population is 65 or more years and only $15 \%$ between 0 and 14 years of age. Thus, for each 100 young people there are 129 elderly people. Since 2001, the number of elderly people has been higher than for young people (with an verified index of 102), which until then had never been registered, for example: in 1970 there were 37 elderly per 100 young people, in 1981, there were 40 and in 1991 there were 68 . The autonomous regions of Azores and Madeira are those that exhibit the lowest indices of aging in the country, respectively 74 and 91, while the Alentejo region has the highest rate (179), followed by the Central region (164).

Table 11: Index of aging in Portugal

\begin{tabular}{cccccccc}
\hline $1980-1982$ & $1984-1988$ & $1988-1990$ & $1992-1994$ & $1996-1998$ & $2000-2002$ & $2004-2006$ & $2008-2010$ \\
\hline 75.15 & 76.27 & 77.30 & 78.09 & 78.88 & 80.01 & 81.30 & 82.05 \\
\hline
\end{tabular}

Source: http://www.ine.pt

Another important factor in the analysis and characterization of our population are their rates of migration. The National Institute of Statistic (INE) indicators for 2008 show a growth rate of $0.09 \%$ migration and natural growth rate of almost zero, with a rate of increase of $0.09 \%$ and thus a further slowdown of population growth, which in 2007 had been $0.17 \%$. 
The Eurostat report, published in June 2010, states that Portuguese rural areas lose their young generations faster than urban areas and indicates that five countries of the twenty-seven EU Member States have a percentage of elderly people living in rural areas higher than 20\% - Portugal, Spain, Italy, France and Greece. It is anticipated that, for the year 2060, an average of $30 \%$ of the population will be 65 years and over in Portugal.

In this context, and with their demographic expression, the elderly population presents itself as a significant part of population, which has a tendency to increase and presents specific needs of living, mobility and accessibility, both within the housing structure, and in the territory where they live and move. The possibility of remaining in their homes and in their reference communities (social and family) will be the biggest challenge for the development of spatial planning and housing. The opportunity to live close to the family (in the same house or with a relationship of physical proximity) is not always presented as a viable alternative. The use of Assisted Residences Homes is revealed as a possible choice, though not always that most desired by the elderly population and their families (Schwarz, 2001). For the elderly population, the possibility to continue in their homes (permanent or temporary), in their territory of domain and knowledge, in their family and in their social communities, helps to promote the proper interaction between the elements of Housing | User | Time.

\section{Home-Villages as a residence and revitalization system of the territory}

\section{The Home-Villages concept}

The concept of Home-Village appeared in Portugal in 1989 with the construction of São José de Alcalar village, in Mexilhoeira Grande, Portimão, presenting itself as an alternative to institutionalization for elderly people.

Its construction was initiated by Father Domingos Monteiro da Costa, after becoming aware of the specific accommodation needs found in the 
Home in the parish. This Home works within a "conventional" structure of shared rooms - differentiated by sex - not taking into account the separation of families or couples who should, despite their age and specific needs, stay together and continue to share the same space, though unable as never before to remain in their homes.

The São José de Alcalar village was designed by the architect Martin Garcias, who developed a composed structure of five cores that respond to the functions of housing, support services for the village, fellowship and support for visitors, arranged in a radial and concentric design.

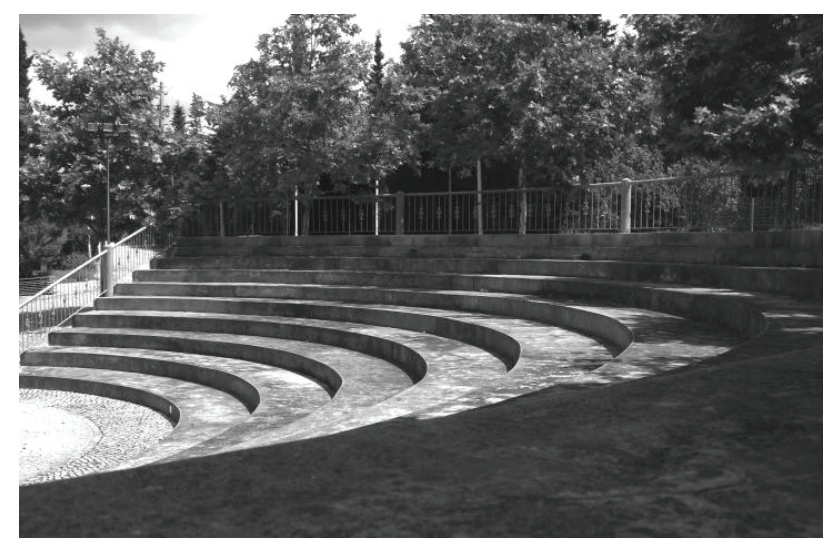

Figure 30: São José de Alcalar Village - Mexilhoeira Grande, Portimão Picture by António Pinto, architect (2011)

The model proposed an intergenerational experience, allowing for the improvement of quality of life of local residents and their interaction with the local community and family, unlimited in its physical space, interconnected with the existing territorial network (Costa, 2000).

In Portugal there are other similar structures, like São Martinho das Amoreiras village (in Odemira, Beja) and Monte da Palhagueira (in Gorjões, Faro), and this model combines residence in single houses and Assisted Living with services dedicated to the specific needs of elderly people, in an urban planning of a village ${ }^{40}$. Another case study, although

${ }^{40}$ Village is understood as a (urban) structure without its own jurisdiction and that in its essence is identified with a rural identity. 
with a different concept from Home-Villages (since this is not the main base of its conception), but as a multifunctional and intergenerational structure, is the village of Santa Isabel (Rio de Mouro, Sintra) property of Santa Casa da Misericórdia de Lisboa, which includes a nursing home, children's home and professional training schools for young people, with a totally cross social component.

The concept of Home-Village includes structures designed and built for this purpose, where all services for its operation are provided, which may vary according to the specific needs of its population and the territory where it stands, as well as the use of towns and villages, in the interior of the country (Portugal), in the process of depopulation and desertification of the territory. These may be the preferred spaces for the installation of housing and support services for the aging population (local, national and foreign) in order to improve their quality of life and simultaneously encourage the setting of the population by creating specialized jobs in the area of geriatrics and long-term care, among others, promoting its intergenerational component.

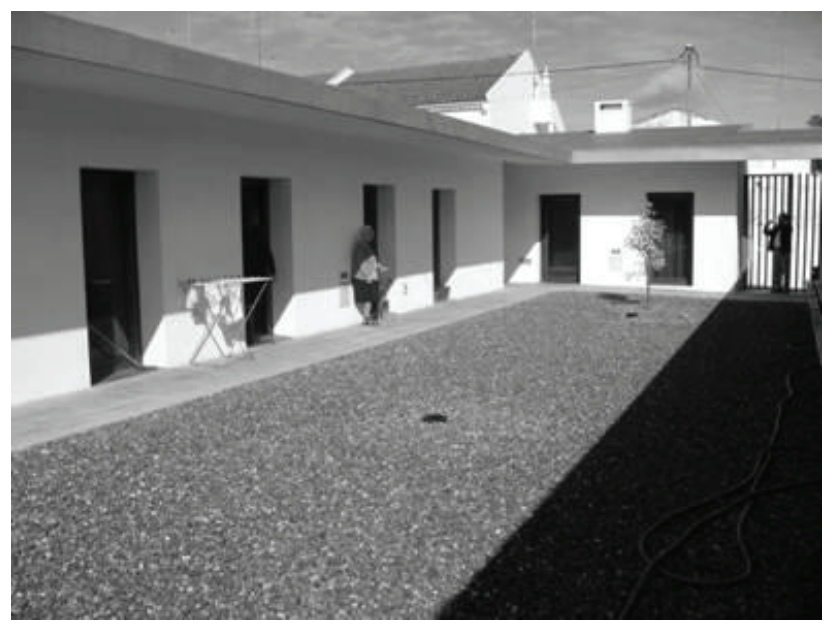

Figure 31: São Martinho das Amoreiras - Odemira, Beja Source: João Martins (2009) 


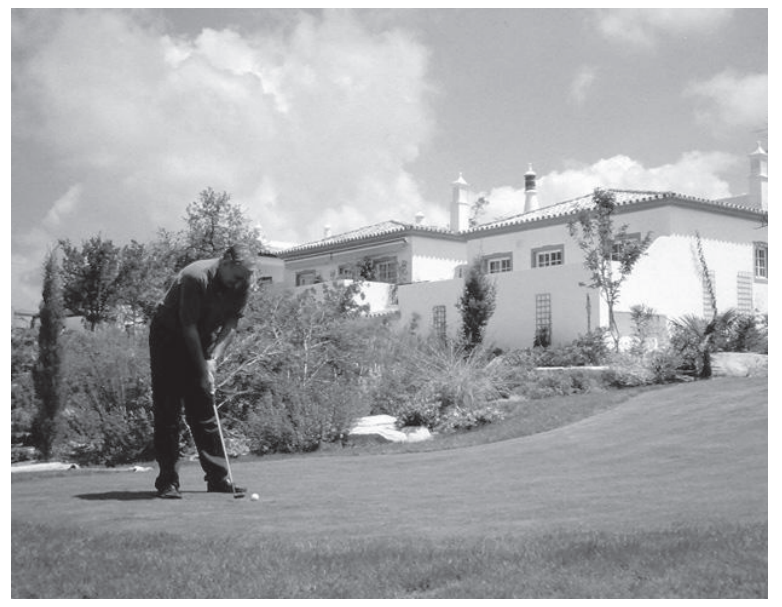

Figure 32: Monte da Palhagueira - Gorjões, Faro Source: http://www.retirementvillageportugal.co.uk

The villages are characterized by their urban structure defined over time of their formation and maturation, with the shared of the experience local community and reconciled with the housing and specialized support services for the elderly population.

As well as a perspective on integration of planning, the Home-Villages may also be a base for tourism and economic development strategies, aimed at seniors, offering specialized services and equipment associated with the different conditions that our territory offers, such as climate, richness of cultural heritage, architecture, landscape and gastronomy. According to Ferreira (2006), the statement of our territory as a destination for international senior European tourism "is founded on the knowledge/ recognition of the factual importance but also on the various implications associated with this demand. From a wider perspective - across the majority of tourism products - to the most confined reading of a certain tourist program profile aimed exclusively or mainly at seniors (product perspective), the national territory and the Algarve in particular, have attributes already marked out and/or with potential to be promoted as holiday destination for the European elderly population". We should also consider that the senior tourists tend to be greater in number, but also older, with greater economic power and more active (Cavaco, 2009), and 
represent, therefore, a stimulating and key factor for economic development of regions and countries with tourism potential.

It is in this context that the importance of integrated and inclusive territorial planning and architectural production arises, and this is where the case of Home-Villages in Portugal can reveal a real alternative to particular problems, not only for a specific (and significant) portion of the population, but throughout the entire social and urban structure. As the fact is that the world's population is aging, this model appears as an alternative to the aging of the territory, facing the context of the desertified interior as a solution and not as a problem.

The villages and towns suitable for Home-Village should be those whose population is already aged, where there is no job's offer and where population loss implies the existence of many empty houses. According to João Martins (2009), this scenario raises the possibility of introducing quality products and services for senior citizens (resident or tourist), through the enhancement and differentiation that the country offers, thereby contributing to better planning, aimed at its revitalization. As well as the improvement of living conditions and establishment of the resident population, by implementing a specialized economic and physical structure, with particular regard to residence services, health and all complementary services (such as laundry, hairdresser, banks, pharmacy, catering, accommodation for visitors, leisure activities, among others) - urbanity.

\section{The Home-Villages framework in the international context}

On the international scene there are similar structures, such as Cohousing, the concept of which originated in Denmark in the 60s, and was subsequently implemented in the Northern Europe and North America, and which also aims to promote intergenerational and integration between the host communities. There are currently Cohousing designed to respond to the specific needs of the population over 55 years old, where they seek to remain "in a housing that promotes good 
neighbourly relations and mutual support to aging with respect, dignity and autonomy" (Daré, 2010).

Other examples of urban structures with similar characteristics, are the expansion of the City of Vienna (Austria) to 10,000 residents, whose urban and architecture planning was designed by architects Peter Ebner and Franziska Ullman. This refers to the inclusion of intergenerational buildings, which allows young families to share their experiences with parents, cohabiting with the existence of small lofts for students. Another example is the expansion of the city of Ypenburg (Netherlands), with urban planning by studio MVRDV, which includes housing for 120 families, and also considers intergenerational issues, relating the developed habitations on different floors with a Home for seniors on the top floor. The architectural project was developed by Van den Oever, Zaaijer and Partners (Schittich, 2007).

In 2004 the Bauhaus Foundation began promoting a project, based on utopian and futuristic models, for medium-sized German cities, targeting the year 2030 .
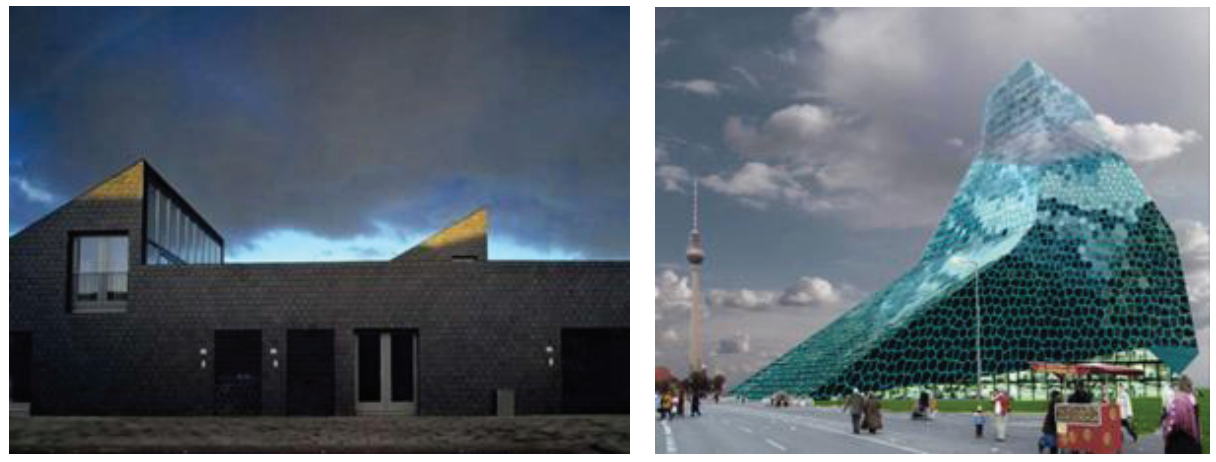

Figure 33: Ypenburg (Holland) ${ }^{41}$

Figure 34: Geropólis conceptual project $^{42}$

\footnotetext{
${ }^{41}$ Source:http://www.flickr.com/photos/sarahlynndunham/3702060529/in/photostream/

42 Source:http://infotechmfp.wordpress.com/2011/12/07.new-aging-reinventing-livingfor-the-second-part-of-life/
} 
This project emerged in order to explore how existing cities may be restructured to promote the satisfaction of its residents and seeks to promote the reduction of isolation among the elderly population, by motivating involvement of the community, based on a new "lifestyle" and a new society. This is founded on sociological, architectural and urban interventions which should have a positive impact, by eliminating barriers and not limiting the range of action of its inhabitants (HOLLWICH, 2010).

Housing for the elderly appears to be one of the actual central focuses of architecture, urban planning and the housing market (HUBER, 2008). In our society the concept of housing / home, is crucial, contributing significantly to the level of quality of life of individuals and their habitat (domain territory). It marks and characterizes our culture and our customs, as well as the political system itself in its legislation, urban planning and architecture programs (HIGINO, 2010). Thus, urban and architectural planning for the future must respond to the specific needs of different population layers (social, cultural, economic, age, physical, etc.). It should also be flexible for different stages of life, in order to promote proper interaction between the physical space and the specific needs of its use in the normal course of life and experience, promoting the autonomy of their users, whether elderly or not.

\section{São José de Alcalar village - Case study}

\section{Framework}

Located in the village of Mexilhoeira Grande, Portimão, São José de Alcalar village presents itself as a relevant case study in the context of housing dedicated to seniors, in Portugal. It goes from a focus on important factors for analysis and interpretation of this habitat system/structure, through the characterization of the elderly residents, to architectural and urban structure - as it was designed to be a Home-Village - and its territory of action and influence. 
Its construction began in 1989 with a structure based on five cores: One central core, where they develop common services to support the village, such as administrative services, lounge, chapel, dining hall, kitchen, medical room, nursing and occupational therapy (for internal and external consultation), a small library, hairdresser and laundry.

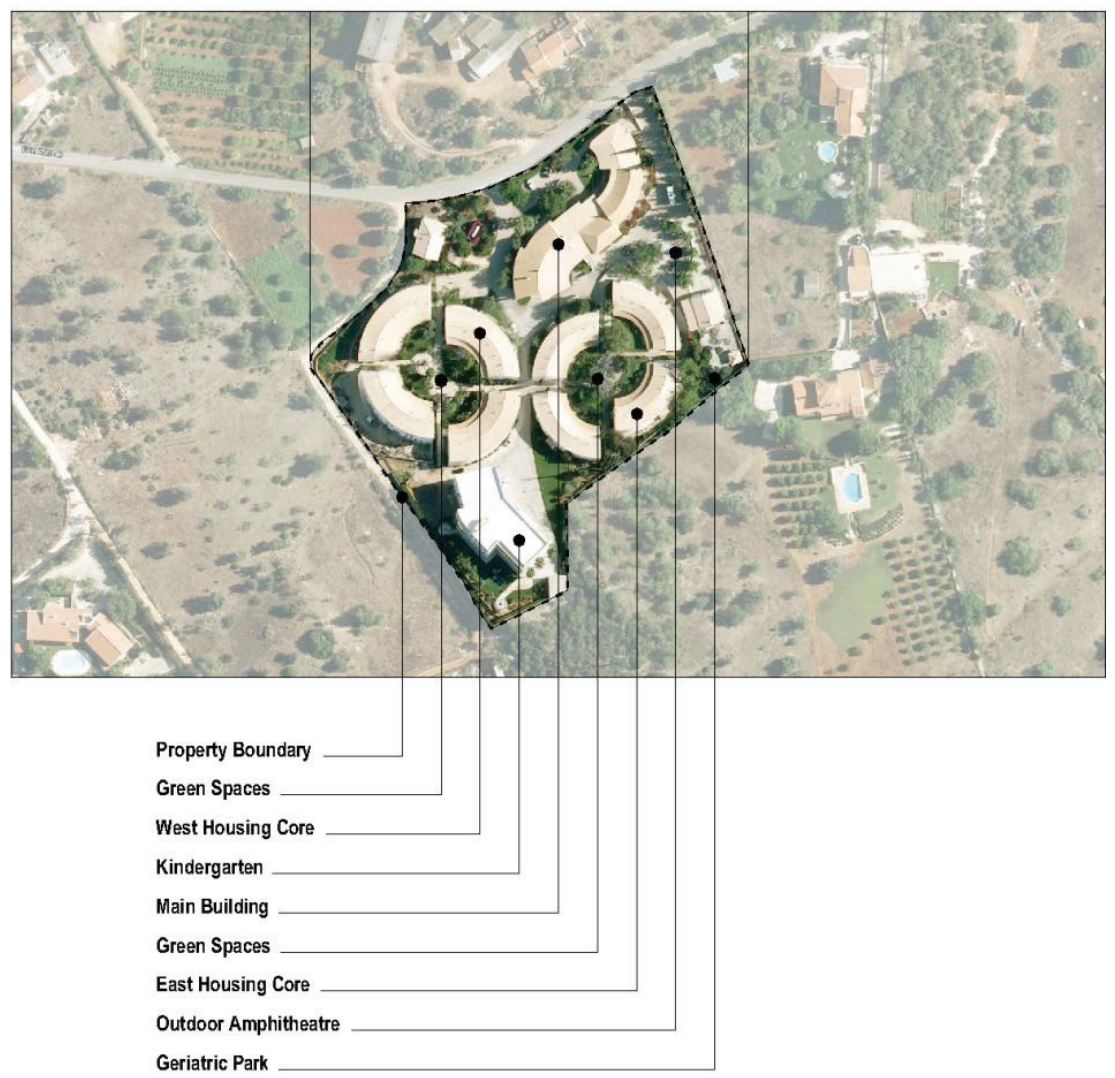

Figure 35: São José de Alcalar Village - Aerial view, Core areas Location

There is another core for living, with open-air amphitheatre, coffee shop, games room and mini-market (not currently functioning), last year a geriatric park was inserted in this core, to carry out fitness exercises. There are two housing cores with single floor townhouses. The fifth core is for visitor support and includes accommodation, a multipurpose room, kitchen and supporting areas and it's in this building that we can currently found a Nursery, a Kindergarten and activity services for leisu- 
re and occupation of young people. Its conceptual structure allows the existence of small gardens, cultivated by the residents.

\section{Characterization of the São José de Alcalar village}

The characterization of São José de Alcalar village was established considering the analysis of its micro-scale, by conducting field work, which included the preparation of survey forms and interviews with its leaders and residents. This analysis was complemented with the analysis of its macro-scale, via the plans of the territory planning.

\section{The macro-scale of São José de Alcalar village analysis:}

Starting from the insertion of São José de Alcalar village in the territory, we considered the following equipment and services for analysis of their neighbourly relations and proximity to the Central Hospital of Portimão; Private Hospital of Alvor; Health Centre of Mexilhoeira Grande and Portimão; Portimão Sports Hall; Municipal Swimming Pool and Tennis Centre; Alvor Sports Centre; Shore - Beaches; Golf Courses; Portimão Marina - Harbour and Airfield - Airport.

It's possible to deduce through the analysis, that São José de Alcalar Village is integrated with its local neighbourhood, giving support to local residents, regarding the possibility of giving medical assistance in the village, as well as use of available services, such as: Coffee Shop; Mini-Market; Geriatric Park; Library; Cultural Activities (parties, festivals, concerts, among others); Nursery; Kindergarten and Leisure Time Activities.

However, it is far from the large urban network, having to rely on the available transport services, such as: Public Transports (that are few), Private Transports and Fire Service, to travel to hospitals and health centres.

These features gives São José de Alcalar village a position of interiority in the territory, where, despite being assured of interaction with 
the neighbouring communities, the distance to facilities and services (such as hospitals, health centres, cultural facilities and sports, among others) have to be travelled in motor vehicles, and the fact that public transport is almost non-existent is presented as a leverage factor of isolation and restriction on the autonomy and mobility of its inhabitants in the territory.

The micro-scale of São José de Alcalar village analysis:

To make the reading of the micro-scale of São José de Alcalar village, we created a survey form and inquiry the local residents and the sponsors of the village (that was carried out in May 2011). We analysed the existing housing typologies, equipment's and available services, which allowed us to establish the physical characterization of the village and of the residential population. For this, it was relevant to program the following four parameters:

1. General characteristics of areas - Relationship of the total area of land $\left(18.820,00 \mathrm{~m}^{2}\right)$, with the built areas of occupation, landscaping, access and outdoor spaces.

Table 12: General Description of Areas

\begin{tabular}{lrr}
\hline Total area of São José de Alcalar village & $\mathbf{1 8 . 2 8 0 m}^{\mathbf{2}}$ \\
\hline Construction area & $5285 \mathrm{~m}^{2}$ & $\mathbf{2 8 . 9 1 \%}$ \\
\hline Housing & $3395 \mathrm{~m}^{2}$ & $\mathbf{1 8 . 5 7 \%}$ \\
\hline Service & $1890 \mathrm{~m}^{2}$ & $\mathbf{1 . , 3 4 \%}$ \\
\hline Accesses and outdoor spaces & $7095 \mathrm{~m}^{2}$ & $\mathbf{3 8 , 8 1} \%$ \\
\hline Green area & $5900 \mathrm{~m}^{2}$ & $\mathbf{3 2 . 2 8} \%$ \\
\hline
\end{tabular}

2. Characterization of the resident population - by age, gender and family structure. 
Table 13: Age Distribution of the Resident Population

\begin{tabular}{|c|c|c|}
\hline Max. cap. of accommodation & \multicolumn{2}{|c|}{130 Inhabitants } \\
\hline Current occupation & 114 & $\mathbf{8 8 \%}$ \\
\hline Men under 65 years old & 5 & $\mathbf{4} \%$ \\
\hline Women under 65 years old & 62 & $48 \%$ \\
\hline Total with less than 65 years & 67 & $52 \%$ \\
\hline Men over 65 years old & 44 & $34 \%$ \\
\hline Women over +65 years old & 3 & $\mathbf{2 \%}$ \\
\hline Total with less than 65 years & 47 & $36 \%$ \\
\hline
\end{tabular}

Table 14: Distribution per family structure

\begin{tabular}{lrr}
\hline Family structure & & \\
\hline Married & 14 & $\mathbf{1 2 . 2 8} \%$ \\
\hline Sons, father and/or mother & 5 & $\mathbf{4 . 3 9 \%}$ \\
\hline Brothers & 2 & $\mathbf{1 . 7 5 \%}$ \\
\hline Other kin & 1 & $\mathbf{0 . 8 8} \%$ \\
\hline Without kin & 92 & $\mathbf{8 0 . 7 0} \%$ \\
\hline
\end{tabular}

Table 15: Distribution of types in the housing structure

\begin{tabular}{|c|c|c|c|}
\hline \multicolumn{4}{|l|}{ Typologies } \\
\hline 1 bedroom & 26 units & 52 & $50.00 \%$ \\
\hline 2 bedrooms & 18 units & 54 & $34.62 \%$ \\
\hline 3 bedrooms & 8 units & 24 & $15.38 \%$ \\
\hline & 52 units & 130 & \\
\hline
\end{tabular}

Characterization of the available services - Medical, nursing, occupational therapies services and other complementary support services available (like: hairdresser, coffee shops, mini-market, church, and others);

Capacity and structure of existing housing - Types, number and characteristics of units; 


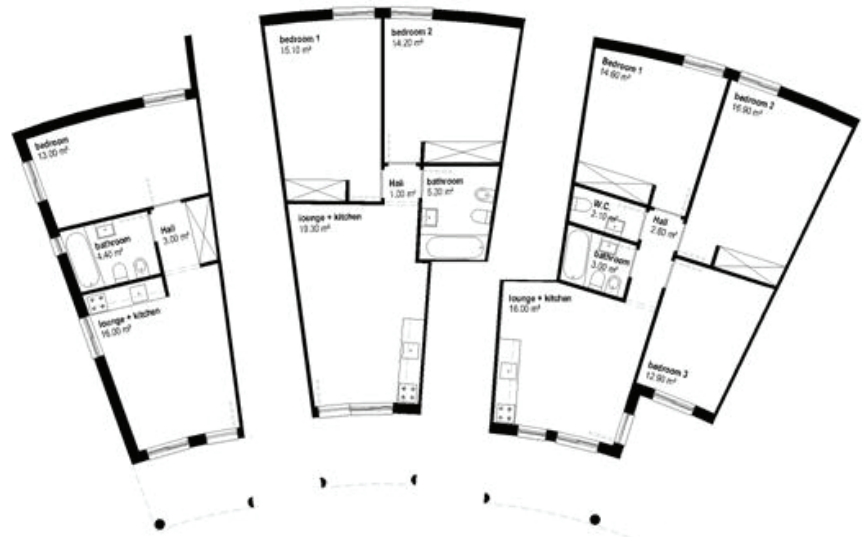

Figure 36: São José de Alcalar Village - Plan of units type T1, T2 and T3 (from left to right)

With regard to the characterization of the resident population and the physical structure of São José de Alcalar village, it's possible to verify that it has a stipulated maximum occupancy capacity of 130 people, in fifty-two apartments consisting of: twenty-six with one bedroom, eighteen with two bedrooms and eight with three bedrooms. The area for housing represents the highest percentage of built area (19\%), however $71 \%$ of the total area of the village is dedicated to access, green spaces, outdoor spaces (amphitheatre, geriatric park, gardens, wasteland, between others), i.e., it is not built.

At the time of the survey, conducted in May 2011, the occupation of the village was 114 inhabitants, of whom 65 were women $(57 \%$ of the total population - mostly under 65 years, 54\%) and 49 were men ( $43 \%$ of the total population - mostly over 65 years, 39\%). Another significant factor in the characterization of the resident population, is the fact that fourteen of the dwellings are occupied by couples (12\%) and eight people with a direct kinship relations (7\%), indicating that most dwellings are shared by people who have no family relationship between them $(81 \%)$.

In this village we can also find an outpatient medical service, a permanent nursing service, occupational therapy and complementary dining room (with own kitchen), laundry, hairdresser, coffee shop, mini-market 
(currently disabled), nursery, kindergarten, leisure time activities for young people, accommodation for visitors and chapel.

\section{Conclusions}

The concept of active aging, launched in 2002 by the World Health Organization introduced a new perspective and a new consciousness in the way we look at the elderly and their contribution to society. It promotes autonomy, independence, with a healthy life expectancy, quality of life in health, safety and social participation, making space to inhabit a major factor in day-to-day populations (elderly) or in the core housing, either in the territory where it stands.

The São José de Alcalar village has a broad range of services geared to the needs of the elderly people available to its residents and the neighbourhood, but is in a position of interiority in the territory, where the distance to the different equipment and services may be a leverage factor of isolation and barrier to autonomy and mobility of its inhabitants in the territory.

The analysis of São José de Alcalar village is part of ongoing research, which involves the analysis of the same parameters of the villages of São Martinho das Amoreiras, Monte da Palhagueira and Santa Isabel village, as a system of planning, as well as the contextualization of the HomeVillages theme in the national and international scenario.

This research seeks to identify and characterize the physical design (on the macro-scale and micro-scale) and the resident population (how many, what age, and with which social, cultural and economic characteristics). The aim, through this reading, is to design structural lines of research, not only from the perspective of architectural design (built for purpose or recovery/revitalization of the existing architectural heritage in villages in the process of depopulation), but also from the perspective of planning, where the insertion of these villages could lead to the sustainability of the place, either as a strategy for tourism and economic development oriented to the elderly. 


\section{References}

Cavaco, C. (2009). Turismo sénior: Perfis e práticas. COGITUR - Journal of Tourism Studies, 2(2), 33-64. Available at http://revistas.ulusofona.pt/index.php/jts/issue/view/56 (March, 2011).

Costa, D. (2000). Aldeia de São José de Alcalar: Uma bem-aventurança viva. Braga: Editorial Apostolado da Oração.

Daré, A. (2010). Design Inclusivo: O impacto do ambiente doméstico no utilizador idoso. Lisboa: Universidade Lusíada Editora - Colecção Teses.

Ferreira, C. (2006). Portugal destino turístico da população idosa europeia: Abordagem geográfica do turismo sénior internacional. Lisboa: Colecção Temas de Turismo.

Gaspar, J. (2009). O envelhecimento e a dinâmica demográfica na Europa: Posicionamento de Portugal. In Fundação Calouste Gulbenkian (Ed.), O Tempo da Vida: Fórum Gulbenkian de saúde sobre o envelhecimento 2008 | 2009 (pp. 51-76). Cascais: Principia.

Harper, S. (2009). Uma abordagem às implicações do envelhecimento global. In Fundação Calouste Gulbenkian (Ed.), O Tempo da Vida: Fórum Gulbenkian de saúde sobre o envelhecimento 2008 | 2009 (pp. 77-104). Cascais: Principia.

Higino, N. (2010). Álvaro Siza: Desenhar a Hospitalidade. Matosinhos: Casa da Arquitectura.

Hollwich, M. (2012). New Aging, Article donated by the author and not published until the date (forthcoming in IBA book).

Huber, A. (ed.) (2008). New Approaches to Housing for the second Half of Life. Berlin: Birkhäuser Verlag AG.

Martins, J. (2009). Aldeias-Lar: Uma alternativa nas Vilas e Aldeias despovoadas. Vila Verde: Seminário Habitação e Inclusão Social. Núcleo Distrital de Braga da Rede Europeia Anti-Pobreza (REAPN).

OMS (2009). Guia Global das cidades amigas das pessoas idosas. Lisboa: Fundação Calouste Gulbenkian. Available at http://www.who.int/ageing/GuiaAFCPortuguese.pdf (April, 2011).

Rosa, M., \& Chistas, P. (2010). Portugal: os Números. Lisboa: Fundação Francisco Manuel dos Santos.

Schittich, C. (Ed.).(2007). Housing for people of all ages: Flexible, unrestricted, senior-friendly. Berlin: Detail Edition.

Wilson, C. (2009). O envelhecimento no século XXI: Perspetivas demográficas. In Fundação Calouste Gulbenkian (Ed.), O Tempo da Vida: Fórum Gulbenkian de saúde sobre o envelhecimento 2008 | 2009 (pp.33-49). Cascais: Principia.

\section{Internet sites}

http://www.ine.pt

http://www.retirementvillageportugal.co.uk

http://www.flickr.com/photos/sarahlynndunham/3702060529/in/photostream/

http://infotechmfp.wordpress.com/2011/12/07.new-aging-reinventing-living-for-the-secondpart-of-life/ 